\title{
Comparative Effectiveness of Online Learning In Higher Education Based On Academic and Applied
}

\author{
Ikhsan Hidayatulloh ${ }^{1}$, Iqbal Mufid Salfiana ${ }^{2}$, Nabila Rinaldi ${ }^{3}$, Nita Nurliawati ${ }^{4}$, Endah Mustika \\ Ramdani $^{5}$ \\ Program Studi Administrasi Pembangunan Negara Politeknik STIA LAN Bandung ${ }^{12345}$
}

\{hikhsan15@gmail.com\}

\begin{abstract}
The Covid-19 pandemic has succeeded in accelerating online-based learning which has long been proclaimed. The effectiveness of learning in higher education, both on an academic and applied basis, is strongly influenced by the online learning process which brings several changes. The study was conducted by comparing the results of a survey conducted by several well-known campuses in Indonesia, namely the University of Indonesia, Padjajaran University, and Gadjah Mada University which has an academic campus background compared with the Polytechnic STIA LAN Bandung as one of an applied campus. The research was conducted using a descriptive qualitative study method. The qualitative-descriptive study conducted was using interview, literature studies on relevant literature sources in the form of accredited journals, news, and various other sources and supported by a survey at the STIA LAN Polytechnic Bandung. The results of the survey from Polytechnic STIA LAN Bandung showed the majority of students chose the offline learning method while at the three academic universities the majority of students wanted mixed learning.
\end{abstract}

Keywords: comparison; effectiveness; type of learning.

\section{Introduction}

Online-based learning which has become an innovation in the world of education will continue to innovate among the academic community as well as the general public since the Covid-19 virus outbreak in Indonesia. The COVID-19 pandemic has forced the birth of onlinebased learning to be present in teaching and learning activities at various levels of education, of course, universities are included. This is in line with the expression of (Dewi, 2020) which states that this learning is an educational innovation to answer the challenge of the availability of varied learning resources. The implementation of online learning is not limited by space and time, which does not require students to always study in the classroom with all rigid rules (Sofyana \& Rozaq, 2019).

Online learning is a learning system that is not carried out face to face, but uses a platform that can help the teaching and learning process that is carried out even though it is distanced (Handarini \& Wulandari, 2020). The purpose of online learning is to provide quality learning services in a massive and open network to reach more and wider interest in learning spaces (Sofyana \& Rozaq, 2019). In terms of the implementation of education, academic education is education that is directed primarily at the mastery of science, while professional education is education that is directed primarily at the readiness to apply certain skills (Law No. 2 of 1989 concerning the National Education System). 
The effectiveness of online learning is the main focus. In several universities in Indonesia, a survey to find out whether online learning is running well and effectively has been carried out before. The present study will answer situational and tentative how the condition of the actual circumstances related to the effectiveness of online learning at different universities base. Effectiveness of learning as a level of achievement of training objectives, achieving these goals in the form of increasing knowledge and skills and developing attitudes through the learning process through efforts, actions or activities carried out systematically to obtain what is the goal by using various supporting information technology-based educational facilities (Rahmawati \& Suryadi, 2019).

In a learning, effectiveness has criteria such as; succeeded in delivering students to achieve predetermined instructional goals, providing an attractive learning experience, actively involving students so as to support the achievement of instructional goals and having facilities that support the teaching and learning process (Rohmawati, 2015). Effectiveness can be measured by looking at student interest in learning activities (Nguyen, 2015).

From the latest PDDikti data, in 2020 the number of higher academic education in Indonesia was 3,403 (74.09\%) while the number of applied education was $1,190(25.91 \%)$. The number of academic students is 7,981,059 $(88.35 \%)$ while the number of applied students is 502,154 $(5.92 \%)$.

To find out how students in Indonesia respond to the most effective learning process according to them, in this article, data from survey results that have been carried out in several Higher Education Institutions in Indonesia will be presented. This research was conducted using a qualitative descriptive research method. Qualitative-descriptive research is carried out using interviews, literature studies on relevant literature sources in the form of accredited journals, news, and various other sources and is supported by a survey conducted at the STIA LAN Polytechnic Bandung.

\section{Comparison of survey results}

Table 1. Comparison of survey results

\begin{tabular}{|c|c|c|c|}
\hline \multirow{2}{*}{ Universities } & \multicolumn{3}{|c|}{ Survey Results } \\
\cline { 2 - 4 } & Online Learning & Learning mix & Offline learning \\
\hline UNPAD & $1,261(68.3 \%)$ & - & $377(20.4 \%)$ \\
\hline UI & $5,298(28 \%)$ & $9,083(48 \%)$ & $4,542(24 \%)$ \\
\hline UGM & $1,262(11,6 \%)$ & $5.897(54.2 \%)$ & $3,721(34.2 \%)$ \\
\hline Poltek STIA LAN Bandung & $48(48 \%)$ & $47(47 \%)$ & $5(5 \%)$ \\
\hline
\end{tabular}

The results of a survey conducted by the University of Pajajaran (UNPAD) showed that the majority of respondents, namely students, wanted the implementation of online learning during the COVID-19 pandemic. The survey was conducted by the Directorate of Student Affairs and Alumni Relations of Padjadjaran University which was attended by 1,857 students. A total of 
$1,261(68.3 \%)$ students really wanted the implementation of offline learning, $377(20.4 \%)$ students gave normal responses, $276(14.9 \%)$ students did not want to carry out offline learning, and $22(1.2 \%))$ students gave responses of not knowing (Maulana, 2021). The results of a survey conducted by the University of Indonesia (UI) on 20,533 respondents consisting of 18,923 students and 1,610 lecturers showed that students and lecturers preferred the implementation ofblended learning. The results of the survey conducted on students were 9,083 (48\%) students chose the implementation of mixed learning, 5,298 (28\%) students chose the full online learning implementation, and 4,542 (24\%) students chose the full offline learning implementation (UI, 2021).

The results of the PIKA UGM survey conducted on March 29 to April 12, 2021 involving 10,880 students showed that the majority of UGM students wanted the implementation of mixed learning. A total of $54.2 \%$ of respondents think that learning is suitable to support the achievement of competence and skills of students usingblended learning(UGM, 2021). Meanwhile, as many as $34.2 \%$ of respondents think that learning is suitable to support the achievement of student competencies and skills using offline learning and $11.6 \%$ of respondents think that online learning is suitable to support student achievement and competency skills (UGM, 2021).

The survey results are an illustration of the implementation of online learning that has been carried out by UGM. The survey results on the indicators of the online learning process show that there are 3 factors that have good scores from an assessment scale of 1-5, namely the quality of the material with an average value of 3.72, the support of other learning resources with an average value of 3.72 , and the delivery process. material with an average value of 3.67 (UGM, 2021). In addition to indicators that have good scores, there are also indicators that still need to be improved, namely the quality of interaction with an average score of 3.40 , ease of skill achievement with an average score of 3.38, quality of assignments with an average value of 3.37, and ease of understanding the material with an average score of 3.12 (UGM, 2021).[NN1]

STIA LAN Polytechnic Bandung conducted a survey on September 9, 2021 on 100 student respondents consisting of $48(48 \%)$ students of the State Development Administration (APN) study program, 25 (25\%) students of the Public Sector Business Administration (ABSP) study program, and 27 (27\%) students of Apparatus Human Resource Management (MSDMA) study program. The majority of students came from the 2018 class, amounting to 54 (54\%), students, the 2020 class 32 (32\%) students, and the 2019 class $13(13 \%)$ students.

The survey results show that the majority of students choose offline learning. The majority of students choose offline learning to improve understanding of the material with the number of students choosing 48 (48\%) students while the rest choseblended learning47 (47\%) students and $5(5 \%)$ students choosing online learning. The majority of students also choose offline learning to improve student competence with the number of students choosing $61(61 \%)$ students while the rest chooseblended learning36 (36\%) students and online learning $3(3 \%)$ students.

The survey results are in line with the views of the majority of students on three types of learning where offline learning has the best value of the other two learnings. In this survey, the indicator used to measure is a linear scale with a score of 1-5 with the lowest score strongly disagree and the highest score strongly agree. In online learning, the three indicators used have a fairly good value where the effectiveness of online learning in increasing understanding of the material has an average value of 3.23 , the ease of understanding the material has an average value of 2.99, and the effectiveness of online learning increases student competence. the average value is 3.13 .

Inblended learning, the two indicators used have good values, where the effectiveness ofblended learning inincreasing understanding of the material has an average value of 3.8 and 
the effectiveness ofblended learning inincreasing student competence has an average score. 3.79. In offline learning, the two indicators used have good scores and have the largest average value than the two previous types of learning where the effectiveness of offline learning to increase understanding of the material has an average value of 4.1 and the effectiveness of offline learning to increase student competence has a value of 4.1. an average of 4.18.

In the results of a survey conducted by universities with academic backgrounds, namely UI, UGM, and UNPAD, the majority wanted a mixed learning process. This is especially true at UI and UGM where the average number of respondents who choose mixed learning is the largest. Meanwhile, in the results of a survey conducted by UNPAD, the majority of respondents chose online learning with the percentage of respondents choosing online learning above $60 \%$. In the results of a survey conducted by the STIA LAN Bandung Polytechnic as an applied university, the majority of respondents wanted online learning. The number of respondents who choose online learning and mixed learning has a thin comparison, namely $48 \%$ and $47 \%$. However, if it is seen from the respondents' responses regarding the effectiveness of both in increasing understanding of the material and increasing student competence, online learning has a higher effectiveness than mixed learning.

The level of understanding and competence of students in online learning has similar results between academic universities and applied universities. In the results of a survey conducted by UGM, the indicator of ease of skill achievement has an average value of 3.38 and ease of understanding the material has an average value of 3.12 where both indicators have the lowest value of the other scores. In the results of a survey conducted by the STIA LAN Polytechnic in Bandung, the indicator of the effectiveness of adding material understanding has an average value of 3.23 , the ease of understanding the material has an average value of 2.99 , and the effectiveness of online learning in increasing student competence has an average value of 3,13 where the three indicators have the lowest value of the other indicators.

It can be concluded that there are differences and similarities in respondents' responses from surveys conducted by both types of universities. The difference that occurs is that the majority of academic college students (UI and UGM) want mixed learning while the majority of applied university students (STIA LAN Bandung Polytechnic) want online learning. The similarity that occurs is that the majority of respondents from both types of universities have the same problems in online learning, especially for understanding the material and increasing student competence.

\section{Conclusion}

Conclusion from the survey results from several universities found two facts that the majority of students wanted direct face-to-face learning even though with different types, namely mixed learning or online learning. In addition, students have difficulties, especially in developing understanding of the material and competencies.

\section{Recommendations}

The government is reviewing the application of face-to-face learning, both in the type of mixed learning or full online learning. Every university improves the quality of online learning, especially in the process of delivering material. 


\section{References}

[1] Dewi, W. A. F. (2020). Dampak COVID-19 terhadap Implementasi Pembelajaran Daring di Sekolah Dasar. Edukatif: Jurnal Ilmu Pendidikan, 2(1), 55-61. Https://doi.org/10.31004/edukatif.v2i1.89 [2] Hikmat, Hermawan, E., Aldim, \& Irwandi. (2020). The Efectivity of Online Learning During Covid-19 Pandemic: An Online Survey. Digital Library, UIN sunan Gung Djati, Bandung, 1-7. Http://digilib.uinsgd.ac.id/30625/

[2] Indonesia, P. R., Rahmat, D., Yang, T., \& Esa, M. (1989). Presiden republik indonesia, dengan rahmat tuhan yang maha esa. 1, 1-17.

[3] Maulana, A. (2021, May 31). Lakukan Survei, 68,3 Persen Mahasiswa Unpad Inginkan Kuliah Tatap Muka. Retrieved September 9, 2021, from Universitas Padjajaran: https://www.unpad.ac.id/2021/05/lakukan-survei-683-persen-mahasiswa-unpad-inginkan-kuliahtatap-muka/

[4] Rahmawati, M., \& Suryadi, E. (2019). Guru sebagai fasilitator dan efektivitas belajar siswa. Jurnal Pendidikan Manajemen Perkantoran, 49-54. Doi:10.17509/14954

[5] Sofyana, L., \& Rozaq, A. (2019). Pembelajaran Daring Kombinasi Berbasis Whatsaap Pada Kelas Karyawan Prodi Teknik Informatika Universitas PGRI Madiun . Jurnal Nasional Pendidikan Teknik Informatika, 81-86.

[6] UGM, P. (2021, June 8). Infografis Survei Kesiapan KBM Bauran - Semester Gasal - 2021/2022. Retrieved September 9, 2021, from Pusat Inovasi dan Kajian Akademik Universitas Gajah Mada: https://pika.ugm.ac.id/id/2021/06/08/infografis-survei-kesiapan-kbm-bauran-semester-gasal-20212022/

[7] UI. (2021, April 19). Hasil Survei UI, Dosen dan Mahasiswa UI Pilih Metode Pembelajaran Bauran untuk Semester Depan. Retrieved September 9, 2021, from Universitas Indonesia: 